\title{
RESPONSI MASYARAKAT DAMPINGAN PADA INOVASI PROGRAM RUMAH PANGAN LESTARI MELALUI KKN-PPM UNISMA MALANG
}

\author{
Masyhuri Mahfudz* \\ Fakultas Pertanian, Universitas IslamMalang \\ *Email Korespondensi: masyhuri.mahfudz@unisma.ac.id
}

\begin{abstract}
ABSTRAK
Program Inovasi Rumah Pangan Lestari (RPL) yang diadopsi dari program pemerintah yang era presiden Susilo Bambang Yudoyono. RPL ini diterapkan Universitas Islam Malang kepada masyarakat Desa Ngenep Karangploso Malang saat melaksanakan Kuliah Kerja Nyata Pemberdayaan Pembelajaran Masyarakat (KKN-PPM) tahun 2013, 2015 dan 2016. Pada tahun 2019, menjadi desa lestari sebagai desa percontohan dan desa asri. Pendekatan yang dilakukan saat itu secara sengaja memberikan tawaran untuk dilakukan menanam sayur-sayuran di sekitar rumah kelompok dampingan. Hasil pengabdian sebanyak 90\% kelompok sasaran menerima. Hal ini mengindikasikan bahwa inovasi tersebut adopternya cukup rendah. Artinya tematik RPL merupakan sebuah ide dan sebuah cara baru yang harus diikuti dengan tindakan riil. Kontribusi RPL pada pendapatan rumah tangga adalah 8-10\% dari kebutuhan konsumsi, namun kontribusi non-ekonomi berupa kelestarian tanaman yang menjadikan faktor esensi program ini sebesar $90-95 \%$ pada tahun 2020 .
\end{abstract}

Kata kunci: inovasi, RPL, ekonomi, lingkungan

\section{ABSTRACT}

The Sustainable Food Innovation Program (RPL) was adopted from a government program in the era of President Susilo Bambang Yudoyono. This RPL was applied by the Islamic University of Malang to the people of Ngenep Karangploso Malang when conducting Community Service Learning (KKN-PPM) Real Work Lectures in 2013, 2015 and 2016. In 2019, it became a sustainable village as a pilot village and a beautiful village. The approach taken at that time intentionally offered to do the planting of vegetables around the house of the assisted group. The results of devotion as much as $90 \%$ of the target group received. This indicates that innovation adoption is quite low. This means that the thematic RPL is an idea and a new way that must be followed by real action. The RPL contribution to household income is $8-10 \%$ of consumption needs, but the non-economic contribution is in the form of plant sustainability which makes the essence of the program 90-95\% in 2020.

Keywords: Innovation, RPL, economic, environment

\section{PENDAHULUAN}

Potensi unggulan sumberdaya di lokasi KKN-PPM Unisma sejak tahun 2011-206 sebagai lokasi KKN dan telah dilakukan kesepakatan antara LPPM UNISMA dan Desa Ngenep melalui MoU sebagai 'laboratorium' sosial ekonomi. Alasan dalam melakukan kerjasama ini karena Desa Ngenep dan Kepuharjo Kecamatan Karangploso meruapakan daerah yang 'dodesa' oleh perkembangan indutri perumahan sehingga lahan pertanian produktif dan no-produktif berupa tegal dan pekarang menjadi alih fungsi cukup significant.

Disamping itu masalah esensi yang harus ditangani adalah terus berkurangnya lahan subur pertanian yang berlaih fungsi untuk industri perumahan akibat peningkatan laju pertambahan penduduk (pendatang), kurangnya kawasan yang asri akibat bangunan perumahan bergandengan dan tercemaranya lingkungan yang sejuk akibat 'berebutnya' supply oksigen. Penyelesaian masalah tersebut implementasi program Rumah Pangan Lestari (RPL) yang telah berhasil dilakukan di Kecamatan Karangploso Desa Ngambon, dengan pemanfaat pembatas rumah, sisa tanah kosong di sekitar kediaman dan/atau trotoar. 
Problematik yang ditemukan saat KKN-PPM semester ganjil-gemap 2012/2013 pada 4 lokasi adalah belum rampungnya beberapa aktivitas yang berkaitan langsung pada pelesatrian lingkungan. Hal ini disebabkan karena masa waktu mahasiswa telah habis dan harus kembali ke kampus, namun perencanaan program tersebut menjadi 'saving' program yang harus diwujudkan untuk periode selanjutnya. Tematik yang akan diusung pada KKNPPM ini adalah kawasan pelestarian lingkungan (KRPL), maka dari itu keberlanjutan program dapat dijamin dengan pengiriman mahasiswa pada tempat dan program yang sama.

Implemntasi ipteks KRPL menjadi indikator tematik dengan metode yang dipakai saat pelaksanaan menggunakan pendekatan Pendekatan analisis yang dipakai adalah action yang dikemukankan oleh O'Brien (2001). Kondisi masyarakat yang masih 'dinanabubukkan' oleh pendapatan rumah tangga mereka melonjakkan diatas rata-rata akibat dari peroleha hasil penjualan lahan pertanian yang dibeli oleh pengembang untuk kebutuhan perluasan industri perumahan. Atas dasar itu, maka ada potensi lalai terhadapa keberadaannya-kelalaian ini diindikasikan bahwa 1 tahun kemudian $85 \%$ mereka mengalami keresahan pada penghidupannya karena uang hasil penjualan lahan pertanian habis yang alokasi penggunaannya bukan untuk dipakai aktivitas produksi tetapi untuk memenuhi konsumsi yang 'terpendam' selama menjadi petani produsen. Dua tahun kemudian mereka sadar bahwa ternyata dalam kehidupan pertanian yang mempunyai lahan pertanian jauh lebih nyaman dibandingkan dengan kehidupan menjadi buruh pabrik dan/atau kerja disektor non pertanian. 3-4 tahun waktu berjalan 60-85\% masyarakat tani menjadi buruh tani di tanahnya sendiri. Realitas inilah mendorong untuk menambah income mereka melalui pemanfaatan lahan pekarangan dan/atau lahan di muka rumah mereka sebagai 'media' dalam melakukan program inovasi RPL.

\section{METODE}

Persiapan dan pembekalan dengan mekanisme pelaksanaan kegiatan, sosialiasi dan pendaftaran. Materi pembekalan, meliputi kemasyarakat tentang teoritis Program community development (CD) dan tematik, tengan Kawasan Rumah Pangan Lestari (KRPL) dan penyusunan program tematik KRPL. Metode yang digunakan, adalah menggunakan metode yang dikemukakan oleh O'Brien (2001) dengan empat gambaran proses action, yaitu: (1) perencanaan (plan) dengan bantuan analisis SWOT untuk mengetahui kondisi riil dampingan; (2) tindakan (action) yang mana kami sebagai fasilitator dan dilakukan demonstrasi kecil sebagai pilot project; (3) pengamatan (observe) sebagai kelanjutan (sustainable) dari analisis SWOT guna menyelesaikan problematika yang terjadi di masyarakat dampingan dan (4) refleksi (reflect) (Novi \& Masyhuri, 2014; Arfarita, et al., 2016; Askandar, et al., 2017; Nurhidayati, et al., 2017; Masyhuri, 2007a; Masyhuri, 2007b; Masyhuri, 2015; Masyhuri \& Nahdhiatun, 2019; Mansur, et al., 2017; Verona, et al., 2006).

Langkah-langkah operasional untuk mengatasi permasalah pada latar belakang, mekanisme yang dijalankan adalah adalah satu/dua/tiga wilayah yang menjadi percontohan dan akan dipanatau secara terus menerus oleh 'petugas' lapang LPPM Unisma. Diantara lokasi yang menjadi bidikan adalah 'kawasan sekitar rumah anggota ibu-ibu PKK' - aparat desa, anggota Karang Taruna dan kelompook partisipan (peng-Hoby) tanaman. Tentunya semuanya akan diambil berdasarkan kesepakatan (agreement) bersaman. Hal ini dapat dikatakan sebagai pilot project atau kawasan percontohan, keberhasilan 'demontrasi' akan dapat dipakai sebagai bukti untuk mengajak para masyarakat secara luas, bahwa ipetks ini cukup inovatif yang dapat mengahasilkan dua kemanfaatan pokok yaitu ke-ASRI-an lingkungan dan nilai ekonomi yang cukup significant.

\section{HASIL DAN PEMBAHASAN}

Target pokok program ini adalah peningkatan partisipasi masyarakat (ibu-ibu PKK, Karang Taruna, dan peng-hoby tanaman) dalam rangka mewujudkan kawasan rumah pangan 
lestari (KRPL) baik pada perkotaan maupun pedesaan. Ada tiga target pokok, (1) terbangunnya kemitraan secara kelembagaan di masyarakat; (2) ipteks yang diadopsikan tidak akan menggeser ipteks yang ada di masyarakat dan (3) ipteks yang diadopsikan akan dapat dilanjutkan oleh kelompok sasaran jika program KKN-PPM telah selesai.

Hasil pengabdian kepada kelompok sasaran saat pelaksanaan KKN-PPM tematik 'RPL' sebanyak 90\% menerima, tetapi saat selesainya mahasiswa meninggalkan lokasi kurang dari $20 \%$ hanya melanjutkan inovasi 'RPL". Hal ini mengindikasikan bahwa inovasi tersbut adopternya cukup rendah. Artinya tematik 'RPL' merupakan sebuah ide dan sebuah cara atau langkah baru yang harus diikuti dengan tindakan riil. Dengan demikian selaras dengan pakar Zaltman Ducan mengatakan bahwa inovasi merupakan ide, tindakan ataupun sesuatu yang ada tetapi diperbaharui oleh sekelompok orang yang mengadopsinya. Dengan kata lain inovasi adalah perubahan.

Komoditas yang dipakai dalam melakukan pelaksanaan program RPL sebagaimana pada Tabel 1 dan Gambar 1a-1c.

Tabel 1: Macam-Macam Sayur-Sayur pada Program RPL

\begin{tabular}{|c|c|c|c|}
\hline 1 & Cabai & Sawi & Kenikir \\
\hline 2 & Kangkung & Selada & Terong \\
\hline 3 & Bayam & Tomat & Kucai \\
\hline 4 & Kubis & Kemangi & Kacang panjang \\
\hline 5 & Daun bawang & Singkong* & $\begin{array}{c}\text { Seledri, Pare, Timun, } \\
\text { oyang,dll }\end{array}$ \\
\hline
\end{tabular}

*sering dilakukan pada lahan pekarang rumah

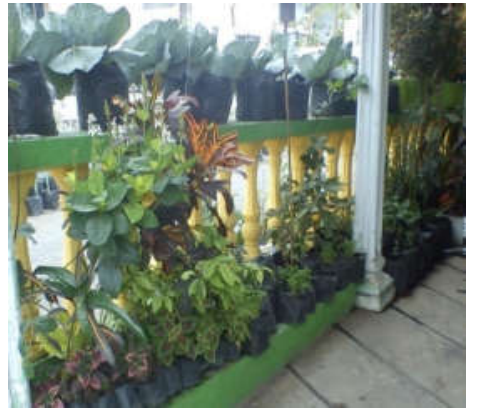

a

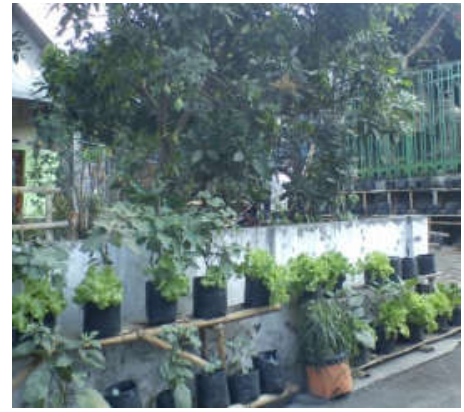

b

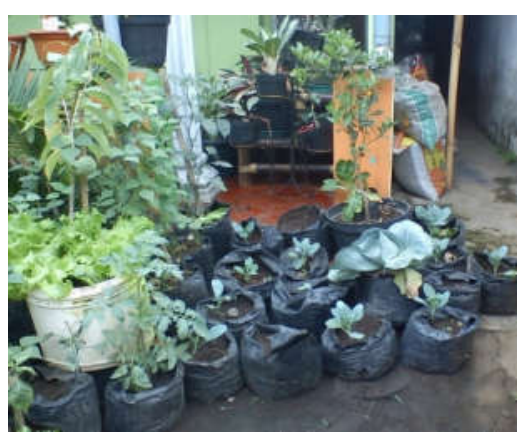

C

Gambar 1a. Tomat, 1b. Sawi, 1c. Kubis

Cabai, kangkung, bayam, kubis dan daun bawang merupakan komoditas yang banyak diusahakan kelompok sasaran. Estimasi kelompok adapter pada komoditas 5(lima) besar ini kisaran $87-90 \%$. Saat pelaksanaan KKN-PPM, namun dalam pelaksanaannya bertahan selama musim panen dan sirkulasi tanaman tidak dilakukan bahkan dibuang serta 
dibongkar. Pada perkembangan selanjutnya selama 4 tahun ternyata ada program pelestarian lingkungan yang diintruduksikan cukup berhasil pada kelompok sasaran. Dengan demikian dapat diimplikasikan bahwa kelompok tersebut diklasifikasi menjadi 3 kelompok yaitu penerima dini, menengah dan penerima lambat. Optimlasi dalam pengabdian ini dilakukan melalui mitra secara kelembagaan yang berada di wilayah Malanga raya juga sebagai daerah sasaran KKN-PPM.

Tiga (3) lembaga mitra yang menjadi kelompok adopter terlibat adalah ibu-ibu PKK, kelopok Karang Taruna dan peng-'hoby' tanaman. Dasar mereka adopter adalah hasil pengabdian periode sebelumnya, maka dari masing-masing profil singkat lembaga terlibat sebagai berikut (i) profil adopter lembaga mitra di Desa Karangkates Kecamatan Karangkates Kab. Malang terdiri dari 40 rukun tetangga, 5 rukun warga, 2 dusun dan terdapat beberapa unsur-unsur terkait pada program ini adalah PKK, Karang Taruna dan masyarakat peng-hoby-tanaman; (ii) adopter lembaga mitra di Desa Kepuharjo Kecamatan Karangploso Kab. Malang terdiri dari 20 RT, 7 RW, 4 dusun juga terdiri dari beberapa lembagan PKK, Karang Taruna dan lainnya; (iii) adopter lembaga mitra di Desa Ngenep Kecamatan Karangploso Kab. Malang. Kondisi Demografis; jumlah penduduk berdasarkan jenis kelamin yaitu laki-laki 6740 orang dan perempuan 6709 dan kepala keluarga berjumlah 3054 kepala keluarga; (iv) adopter lembaga mitra di Kelurahan Dinoyo Kecamatan Lowokwaru Kota Malang. Kondisi demografis, Jumlah Kepala Keluarga (KK) : 2.892 dan Penduduk awal : 15.549 dengan jenis laki-laki : 8.382 dan perempuan : 7.287 dan (v) adopter lembaga mitra di Desa Kelurahan Merjosari Kecamatan Lowowkwar Kota Malang. Jumlah penduduk sebanyak 16.839 jiwa, RT 80 RW 12.

Dengan demikian jumlah lembaga mitra sebanyak 15 yang terdiri dari 5 ibu-ibu PKK, 5 lembaga Karang Taruna dan 5 kelompok adoptes-masyarakat peng-hoby-tanaman. Pada 15 lokasi sasaran ini sebagi pilot project kawasan tertentu yang dipilih berdasarkan kesepakatan antar pihak. Diharapkan potensi keberhasilan ini dapat ditumbuhkembangkan sehingga mampu menjawab seluruh tujuan pokok program ini, ternyatan $90 \%$ respon baik meskipun disadari bawha dia butuh waktu.

Kontribusi RPL pada pendapatan rumah tangga $8-10 \%$ dari kebutuhan konsumsi, namun kontribusi non-ekonomi berupa kelestarian menjadikan faktor esensi program ini dijalankan lagi oleh masyarakat 90-95\% masyarakat kelompok sasaran pada Desa Ngenep tahun 2020 per januari adalah mengadopsinya. Dengan demikian kelompok masyarakat ada tiga katagori adopter dini, menengan dan adpter lambat (Masyhuri,2007). Kontribusi nonekonomi ini mempunyai peluang untuk dilakukan kajian (penelitian) yang lebih mendalam karena pada bahasan artikel ini pada aspek pengabdian dengan indikator riil berupa pengaruh pada income secara rii. Dengan demikian pengembangan secara keilmuan dan/atau secara program perlu melakukan program riset secara mendalam.

\section{DAMPAK DAN MANFAAT}

Sayuran yang direkomendasikan pada aktitas prongan inovasi RPL ini adalah mudah untuk dilakukan dengan budidya pemanfaatan lahan sekitr rumah. Dampak keindihan dan keasrian sangat kental sekali.

Adopsi inovasi program RPL yang mempunyai dampak dari aspek di atas, mendorong pada masyakarat lainnya untuk mencontohnya sehingga ter-interkasi dengan lainnya yang mempunyai akselerasi cukup tinggi sehingga 99\% rumah terdapat tanaman sayur-syuran. Dominasi ini secara sepintal lewat di wilayah desa Ngenep kelihatan wilayah hijau sehingga desa ini menjadi desa percontohan dalam program RPL

Masyarakat tidak perlu perlu repot-repot lagi untuk mengurusnya, karena selain mudah ditanam, menanam sayuran dirumah juga dapat membuat biaya belanja bulanan rumah tangga berkurang karena kebutuhan dapat dipenuhi dari sekirtar kawasan rumah mereka sepeti cabai, kubis, kecang panjang, seledri, bahkan buah seperti mangga, sawo dan sebagainya. 


\section{KESIMPULAN}

Hasil pengabdian kepada kelompok sasaran saat pelaksanaan KKN-PPM tematik 'RPL' sebanyak 90\% menerima, tetapi saat selesainya mahasiswa meninggalkan lokasi kurang dari $20 \%$ hanya melanjutkan inovasi 'RPL". Hal ini mengindikasikan bahwa inovasi tersbut adopternya cukup rendah. Artinya tematik 'RPL' merupakan sebuah ide dan sebuah cara atau langkah baru yang harus diikuti dengan tindakan riil. Kontribusi RPL pada pendapatan rumah tangga 8-10\% dari kebutuhan konsumsi, namun kontribusi non-ekonomi berupa kelestarian menjadikan faktor esensi program ini dijalankan lagi oleh masyarakat 9095\% masyarakat kelompok sasaran pada Desa Ngenep tahun 2020 per januari adalah mengadopsinya.

Dari hasil pembahasan ini dapat direkoemndasikan bahwa satu aspek yang perlu dilakukan kegiatan tindak lanjut, yaitu penelitian dari aspek dampak pada lingkungan masih belum dibahas secara mendalam. Untuk itu potensi untuk dilakukan penelitian dan pengabdian guna melengkapi dari kekurangan pada aktivitas ini.

\section{REFERENSI}

Novi, A. dan Masyhuri, M. (2014) 'Direct and Residual Effect of Various Vermicompost on Yield and Quality of Broccoli', Journal of Applied Science Research, 12(3), 36-45.

Arfarita, N., Hidayati, N., Rosyidah, A., Machfudz, M. dan Higuchi, T. (2016) 'Exploration of indigenous soil bacteria producing-exopolysaccharides for stabilizing of aggregates land potential as biofertilizer', Journal of Degraded and Mining Lands Management, 4(1), 697-702.

Askandar, N. S., Machfudz, M. dan Junaidi, J. (2017) 'Implementation Of Innovative Corporate Social Responsibility (CSR) Model In Indonesia', International Journal of Technology and Sciences, 1(2), 11-15.

Nurhidayati, Masyhuri, M. dan Indiyah, M. (2017) 'Combined Effect of Vermicompost And Earthworm Pontoscolex Corethrurus Inoculationon The Yield and Quality Of Broccoli (Brassica oleracea L.) Using Organic Growing Media', Journal of Basic and Applied Research International, 22(4). 148-156.

Masyhuri, M. (2007a) 'Model pengembangan sektor pariwisata alam (agro eco tourism)', Agritek. 960-969.

Masyhuri, M. (2007b) 'Analisis deskripsi permintaan dan penawaran sektor pariwisata dan lingkungan', Agritek, 197-202.

Masyhuri, M. (2015) 'Optimalization of Cassava Distribution and Marginal Area Usage for Supporting Food Endurance’, International Journal of Applied Engineering Research, 10(1), 0973-4562.

Masyhuri, M. dan Nahdhiatun, K. (2019) 'Empowerment of Small Businesses through The Implementation of Qardhul Hasan Financing', Journal Socioeconomics and Development, 2(2), 99-106.

Mansur, M., Masyhuri, M. dan Widarko, A. (2017). 'Revitalisation of Smes' Creative Businesses In Indonesia To Face Asean Economic Free Trade', International Journal of Engineering and Management, 1(2), 33-39.

Verona, G., Prandelli, E. dan Sawhney, M. (2006) 'Innovation and Virtual Environments: Towards Virtual Knowledge Brokers', Organization Studies, 27(6), 765-788. 